\title{
マレイシアにおける法制度と 法学教育の動向について
}

\section{宮 坂 富之助}

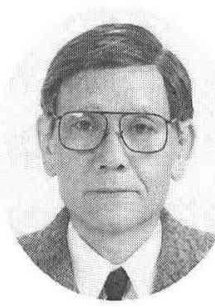

\section{（1）「アジア法」研究の重要性}

(1) 中国、台湾、香港、シンガポールなど とともに、近年著しい経済成長を遂げている マレイシア。2020年までにはほぼ先進国に伍 する経済発展を目標に、国をあげて政策の達 成を計画し、国際政治の面では、日本を含め 欧米先進国の政治的・経済的な「覇権」を质 け、アジア諸国の強い組織的協力と連帯のな かから平和と「持続的な発展」を呼び続けて いるマレイシア。歴史的には、ヨーロッパ諸 国の経済的・政治的な支配と文化の影響を受 けながら、宗教と民族・人種の面で、著しく 多様な社会構造をもつ国。

以上がマレイシアについての、私のイメー ジの要約である。科学の領域での相互交流に は多様な視点と課題が考えられるが、こうし たマレイシアの政策上の背景から浮かび上が る私の課題意識は、社会科学の領域での人材 教育の現状がどのようであるか、なにが課題 となっているか、であった。こうした視点に よる知見の蓄積は、今後の研究交流の重要な 前提となる、と考えるからである。

(2) そこで、あかじめ私が始めた準備は、 このようなイメージに基づいて「現代のマレ イシア」に関する各種資料を調査することで あった。対象は主として経済、法制度につい ての現状分析に属するものであるが、作業を 進めるうちに、この領域での日本人研究者に よる「マレイシア研究」の現状が徐々に見え てくる思いがあった。ひとことで言えば、同 じく経済的な分析であっても、他のアジア諸 国、例之ば中国についてのものに比べて、は るかに少ないという印象をもつことである。
もつとも、この点について誤解をうけぬよう 述べると、最近のマレイシアに打経済発 展に伴う諸問題についての、アジア経済研究 所による一連の研究は、今回私なりに認識を 深める上で多大の示唆を受けている。した がって「少ない」という印象は、あくまで相 対的な意味合いである。

また法律学の領域でみると、最近ではアジ ア諸国の法律学者・法曹たちが一堂に会し、 主として経済開発に伴う国民生活への影響を 中心に、人権の保障あるいは環境保全の視点 から国際会議を開催するなど、アジア諸国の 法律問題への関心を強める傾向がみられる。 しかし、立ち入ってみると、そうした努力と は別に、個々の国の法制度に関する研究とし て言えば、マレイシアに関するかぎりでは、 相詨的に少ないと言えるようである。

(3) なぜ法律学の領域一この場合主として 外国法研究あるいは比較法学であるがーでは このような研究状況となっているのか。もち ろんその要因は一様ではない。この要因を考 えることは、今後のアジア法研究を推進する にあたっての出発点として、重要な課題であ る。また、つとに比較法学研究者が指摘して きたように、外国法制度の研究にはそれぞれ の国・民族をめぐる歴史的な背景、政治・経 済そして社会的な構造の考察、さらには「活 きた法」としての慣習法などの諸要素の考察

宮坂富之助（みやさかとみのすけ 1930年生） 日本学術会議第 2 部会員、社会法学研究連絡委員会 幹事、法学政治学教育制度研究連絡委員会委員、早 稲田大学法学部教授、法学博士 専門：社会法学 
をぬきに成立しえない。

もちろん、このような方法そして問題意識 に基づく研究は容易ではないが、最近ではこ のような課題に応えようとするアジア法研究 があり、今回の訪問にあたって私は多大の示 唆を得ることができた。安田信之「アジアの 法と社会」(1987年、三省堂) がそれである。

(4) 現在、経済発展の政策をすすめるアジ ア諸国は、法制度の整備を重要な課題として いる。その場合の「法制度」とは、多くの場 合市場経済システムを前提とするのであるか ら、近代法原則を基礎として、その上に現代 的な修正が加わった現代法の体系を意味して いるのであり、同時に、国際経済の進展に伴 い急速に展開し始循連の「国際経済法」 のシステムである。このような法制度の整備 の作業に研究者が何らかの協力をおこなうと すれば、その場合の基本姿勢は、当該国や社 会がもつ歴史的な伝統と宗教に根ざす法文化 の独自性に目をむけ、これを尊重することに おかれなければならない。

このように考えると、法律学の領域での国 際的な学術協力・交流には、前記のような方 法を主とするアジア法の研究が重要な意味を もつ、と言わざるを得ない。

(5) 今回の訪問にあたって、関係機関での 質疑項目に法律制度・法学研究に関するもの を設けて頂いたのは、以上のような問題意識 によるのであるが、滞在期間など限られた条 件に制約され、意図した成果を十分には達成 できなかった。しかし、西島団長はじめ諸先 生のご協力を得て、今後の学術研究交流に とって前提となる基礎的な知見を得ることが できたこと、また同時に、自然科学・人文科 学の諸先生による質疑を通じて、多大の有益 な示唆を得ることができたことに感謝した い。
（2）マレイシアにおける法学教育・

\section{研究の動向}

ごく短期間の、しかも限られた条件のなか で知り得たことのみで「動向」を述べること に臆するものがあるが、大学をはじめ関係機 関から提供された資料、滞在期間中の短い合

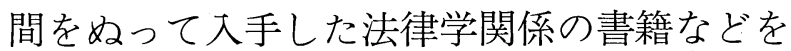
素材にして、ごく限られた視点ではあるが「動 向」の一端と考えることを記すことにしたい。

(1) マレイシア法の特質と法学教育・研究 マレイシアの政治的・社会的な歴史の構造、 そして宗教、人種、民族の多様性については よく指摘されるところである。当然に、こう した諸要素は、法律制度の在り方、法学教育・ 研究の内容にも反映する。このような諸要素 のうち、とりわけ宗教と歴史的なイギリスの 政治支配は、慣習法など社会規範を含む広い 意味での法規範の内容を規定している。

このことを具体的に言えば、イギリスのコ モン・ローとエクイティの部分的な継受とイ スラム法の共存関係が特質のひとつであり、 また、ADAT とよばれるマレー社会の規範で ある慣習法、事実としての慣習が重要な法源 とされていることも特徵的である。

これらの法規範は、不文法としての判例法 であるが、現代のマレイシア法の体系ではこ うした不文法とともに、連邦憲法をはじめ多 くの成文法＝制定法もまた主要な位置を占め ている（このような各種の法源形態について は、Wu Min Aun、The Malaysian Legal System, 1990. Longman Malaysia に要領よ くまとめられている)。

ところで、私自身がそうであるが、欧米諸 国の法系に親しんできた研究者にとって、イ スラム法の体系と実態の理解には困難を感じ る。この点について、ある研究者によれば、 「イスラム法の規範としての本質的な根源そ して規範力は、神の命令・指示を体現するコー 


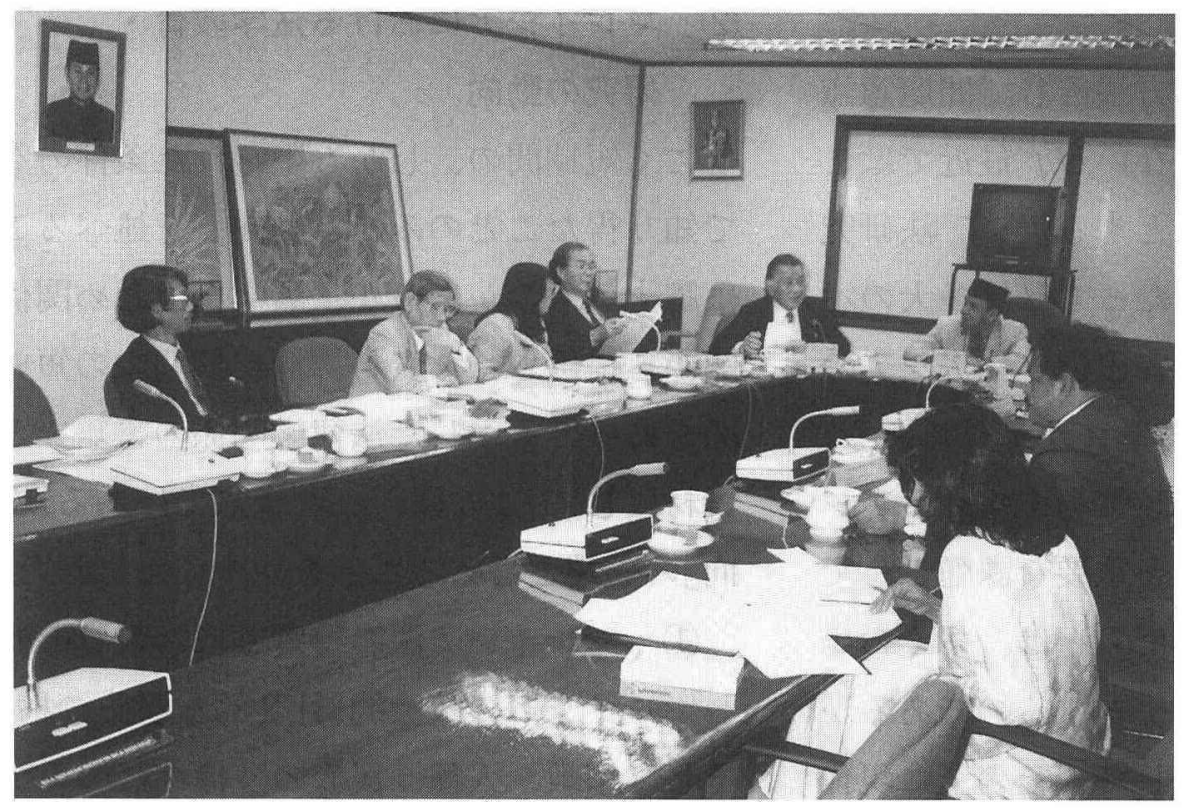

教育省にて（6月11日）

ランに由来するものであって、神が啓示する 規範 (“revealed law”) である。この意味で、 人間相互の意思関係に基づき形成される法規 範 (“human law”) とは異なる」という趣旨 の説明がなされている (Anwarul Yaqin、

Law amd Society in Malaysia, 1996. International Law Book Services)。

このような法規範としてのイスラム法は、 イスラム教の教義を信奉する教徒にとって は、法規範であるだけではなく広く社会的、 道徳的な行為規範でもある。このように宗教 規範と法規範の二つの性格をもつイスラム法 の規範力がどのように確定されるかは、民族 と宗教の多様性を含む統一国家と社会では重 要な課題である。この点について、連邦憲法 第 3 条は、イスラム教が連邦の宗教であるこ とを規定し、同時に他方では、他の宗教との 共存を定め、さらに第 11 条 1 項が個人の信教 の自由を規定している。したがって、イスラ ム法は、イスラム教徒としてのマレー人に適 用される規範であり、司法手続面では、イス ラム裁判所である Syariah courts の管轄下 におかれる。また、連邦憲法は、イスラム教 徒へのイスラム法とその家族法の適用につい て定めるところである(この詳細については、
前掲書 Wu Min Aun、32頁以下を参照)。

さて、以上の上うな法制度の構造の特質は、 法学教育や研究にも反映する。訪問した大学 そして教育省での説明や質疑にも、この特質 がかかわっている。教育省が、人材育成の基 本的な目標に、法意識あるいは遵法精神の向 上を挙げる場合、そこでは、多数を占めるイ スラム教徒としてのマレー人を前提に、イス ラム教とイスラム法が強く意識されていると の印象を強くした。また、大学教育でも、イ スラム法とりわけイスラム家族法の教育と研 究が重要な位置を占めていることが理解され た。

(2) 法学教育と法曹育成

法学教育と法学研究は、裁判官・弁護士な どいわゆる法曹の育成のみに向けられるわけ ではない。しかし、法律学者の論文や書籍に みる限りではあるが、現代のマレイシアに専 門職の法曹の必要性が強調されていること が、印象的である。大学教育の重点が自然科 学系におかれ、法学部の設置が比較的最近で あることは、そのことを裏づけることである。 私が関心を強くするのは、こうした法曹育成 あるいは教育の機会が、歴史的な経緯も反映 して、イギリスあるいはオーストラリアなど 
の大学に求められ、そのことが海外留学の傾 向を強めるという状況である。

マレイシアの The Legal Profession Act (1976)によると、弁護士資格は、マラヤ大学 などの LL.B、を有することのほか、the Bar Councilの定める資格条件のなかにオースト ラリア、ニュージーランドの各大学の LL.B が挙げられている。おそらく、イスラム法と ならんでイギリ久法の影響を受けた法制度で あることがそうした条件を設けたものと想像 されるが、いずれにせよ、法律専門職の資格 を得るためにこうした留学を条件づける結果

\section{としているわけである。}

教育省の関係機関での説明のなかに、今後 の基本方針として、国内の大学教育の充実を はかる一方、従来促進してきた海外留学生を 縮小するという方針が示されたことを想起す るが、法曹のみならず広く法律の教育を受け た人材の育成が、大きな課題となっていると の感をつよくする。

(3) 法学の研究関心の動向

大学における研究者の研究関心は、当然に 教育内容にも反映するのであるから、研究関 心のいかんは、大学学部・大学院の教育科目 の設置傾向にも及ぶ。伝統的なイギリス法や イスラム法の研究とは別に、例えば知的財産 権の保護やWTO をめぐる問題など、現代の 国際的な経済問題を反映する法律問題や法制
度への関心が強まっているという印象であ る。とりわけ、市場の国際化、海外資本の導 入の促進などに伴う国内法制度の整備と調和 策の必要性は、ますます強まると考えられる。 訪問した大学の教員による論文の多くが、そ うした国際的な経済法にかかわる課題に取り 組んでいることは、現代のマレイシアにおけ る法律学の関心の大きな流れを示すものと言 えるようである。

もうひとつの法律学の動向を示すのは、例 えば環境保全や医療制度の改革をめぐる問題 など、経済発展政策とともに生ずる国内の経 済的社会的な諸問題とその法律問題をめぐる ものである。帯在中に入手した前掲の法律書 Anwarul Yaqinの著作、あるいは、R.H. Hickling, Essays in Malaysian Law, 1991. Pelanduk Publicationsにおいても、そうし た国内の法律制度を国内の諸課題と結びつけ て論及されている。

こうしたマレイシア国内の法律問題には、 現代の経済社会に共通の論点も含まれてい る。このような二つの大きな動向をうけて、 あるいは研究者のレベルでの研究交流、ある いは若い青年留学生の受入れの制度面の充実 のための再検討など、国際的な交流の場を多 く設定する必要性が強まっているという感を 深くする。

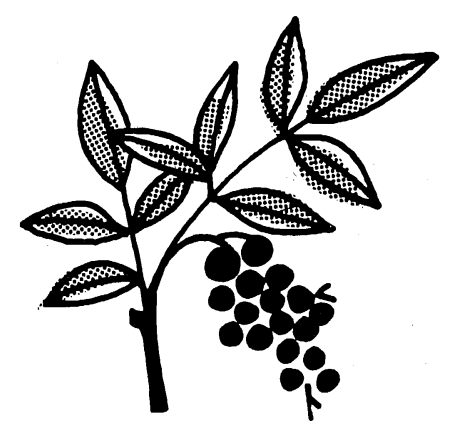

